\title{
KALIMAT PENOBATAN RAJAs LOGIKA SEMIOTIK ORANG MORONENE DI PULAU KABAENA
}

\section{THE KING CORONATION SPEECH: SEMIOTIC LOGICS OF MORONENE PEOPLE IN KABAENA ISLAND}

\begin{abstract}
Heksa Biopsi Puji Hastuti
Kantor Bahasa Provinsi Sulawesi Tenggara

Jalan Haluoleo, Kompleks Bumi Praja, Anduonohu, Kendari, Indonesia

e-mail: heksa.biopsi@kemdikbud.go.id

Abstrak

Kalimat penobatan Raja Moronene di Kabaena cikal bakalnya adalah pesan perpisahan Tebota Tulanggadi kepada putranya yang terdapat dalam legenda "Donsiolangi dan Wa Lu Ea". Penelitian ini mengangkat permasalahan tentang bagaimana pandangan filosofis orang Moronene di Kabaena terhadap posisi raja sebagai pemimpin tertinggi negeri, yang tercermin dari kalimat penobatan raja yang ada dalam legenda ini. Data berupa lima kalimat perpisahan raja dan anaknya diambil dari kisah legenda "Donsiolangi dan Wa Lu Ea". Data dianalisis secara deskriptif-kualitatif dengan pendekatan semiotika. Hasil analisis data menunjukkan bahwa pandangan filosofis orang Moronene di Kabaena terhadap seorang raja adalah bahwa raja harus amanah dan mutlak berlaku adil pada rakyatnya; Raja harus berhati-hati dan penuh pertimbangan dalam mengambil putusan. Tanggung jawab sebagai raja dapat membalikkan kejadian; Kebijakan raja sangat berdampak bagi negerinya, baik dampak positif maupun negatif; dan Raja harus selalu siap menjawab pertanyaan dan mencari solusi bagi segala permasalahan rakyatnya.
\end{abstract}

Kata kunci: Kalimat penobatan raja, Moronene, logika semiotika.

\begin{abstract}
The Moronene king coronation speech in Kabaena was sourced form the farewell messages of Tebota Tulanggadi to his sons which is contained in the legend "Donsiolangi and Wa Lu Ea". This research concerns issues on Moronene philosophical point of view upon a king as top leader in a country, which represented in king's coronation speech. The data was taken from "Donsiolangi dan Wa Lu Ea" legend that was told by Ilfan Nurdin, S.Ag. Analysis data were committed by using qualitative-descriptive method with semiotics approach. The result of data analysis shows that Moronene' philosophical views upon king is that a king requarely to be trust and fair to his people. The king must be careful and considerate in taking decisions. Responsibility as a king can reverse any circumstances; The king's policis greatly affected his country, both positive and negative; And the king should always be ready to answer questions and seek solutions to all the problems of his people.
\end{abstract}

Keywords: King coronation speech, Moronene, semiotic logics. 


\section{A. PENDAHULUAN}

Masyarakat

melahirkan

kebudayaan untuk difungsikan dalam kehidupannya. Penalaran kolektif suatu masyarakat direpresentasikan dalam produk budayanya, termasuk sastra lisan. Perepresentasian ini tentunya tidak terlahir secara serta merta. Proses panjang pembentukan budaya harus dilalui demi melahirkan produk yang matang, siap digunakan dan dimanfaatkan sekaligus dinikmati oleh masyarakat pendukungnya. Ratna (2011: 105) menyatakan bahwa pada masa sekarang biasanya sesuatu yang terkait dengan kerakyatan (folk) dan kelisanan (orality) dianggap sebagai paham pralogis dan primitif. Padahal, sebagai produk hasil pemikiran komunal, sangat mungkin banyak hal positif di dalamnya yang tetap dapat ditarik relevansinya dengan keadaan sekarang.

Kisah "Donsiolangi dan Wa $\mathrm{Lu}$ Ea" memuat perjalanan peradaban awal di Pulau Kabaena. Dimensi mitologis dan historis teramu di dalam tahap-tahap alur ceritanya. Dalam kajian antropologis, tahapan-tahapan dalam sebuah produk budaya lisan mengemban fungsi-fungsi tertentu (Vansina, 2014). Dibuka dengan tahap mitos yang berhubungan dengan masa lalu yang tak berhingga kelampauan waktunya. Lalu dilanjutkan pada tahap kedua yang merupakan masa pertengahan, umumnya pada tahap ini sarat akan inti muatan yang disisipkan sebagai pesan moral yang bersifat filosofis. Tahap ketiga merupakan penautan pada waktu yang linear.

Dalam posisinya sebagai sastra lisan, ketumpangtindihan ini cukup menyulitkan penentuan kategorinya, termasuk dalam mitos atau legenda. Dengan pertimbangan kentalnya aspek kesejarahan orang Moronene Kabaena di dalam kisah "Donsiolangi dan Wa Lu Ea", cerita ini diklasifikasikan sebagai legenda (Hastuti, 2015). Legenda ini diyakini oleh masyarakat pemiliknya sebagai sebuah peristiwa yang benar-benar pernah terjadi dengan benda-benda alam yang dianggap melekat pada aspek kesejarahan peristiwa dalam kisahnya ${ }^{1}$. Keyakinan akan adanya kaitan antara benda alam dengan sebuah kisah lisan juga ditemukan pada cerita Moronene lainnya, "Putri Lungo". Orang Moronene meyakini lesung batu di tepi sungai di Kabaena sebagai alat untuk memanggil seorang putri bidadari yang akan turun dalam bentuk hujan (Hastuti, 2016). Konsep pengaitan seperti ini sifatnya universal, misalnya, ada juga keyakinan bahwa dua kuburan di dekat Jembatan Sewo merupakan kuburan tokoh dalam cerita "Saedah dan Saeni" sebagai penguat anggapan bahwa kisah tersebut benar-benar pernah terjadi (Purnama, 2016). Kemelekatan benda-benda alam sebagai bukti kebenaran sebuah kisah, yang biasanya disampaikan secara lisan, dapat dijadikan salah satu ciri legenda.

Sebagai karya sastra, sebuah legenda terbentuk sebagai hasil pemikiran, perenungan, imajinasi, pengamatan, dan pengalaman penciptanya dalam masyarakat pendukung di mana legenda itu lahir (Yulianto, 2015). Dalam kaitannya dengan hal ini, legenda "Donsiolangi dan Wa Lu Ea" lahir dan hidup di dalam budaya suku Moronene di Pulau Kabaena. Apa yang tertuang di dalamnya merupakan hasil pemikiran kontemplatif sehingga menghasilkan ekstraksi petuah leluhur karena sebagai produk kolektif, kisah legenda ini dihasilkan oleh orang-orang tua zaman dulu yang sifatnya anonim.

Kalimat dalam pesan sang tokoh ini digunakan sebagai bagian dari kalimat penobatan mokole di Kabaena hingga saat ini. Komposisi penduduk di Pulau Kabaena yang relatif homogen (suku Moronene), memungkinkan mereka untuk setia mempertahankan kearifan budaya leluhur sebagai panduan hidup. Hal ini analog dengan yang terjadi pada saudara mereka

\footnotetext{
${ }^{1}$ Orang Moronene di Pulau Kabaena meyakini sumber air yang biasa disebut oneni dundu muncul di tempat jatuhnya cincin Daeng Masaro Lampi, salah satu tokoh dalam segmen akhir legenda ini.
} 
sesama suku Moronene di Hukaea-Laea ${ }^{2}$ yang masih mempertahankan sistem dan pranata sosial lokalnya secara terinstitusional (Muis, 2015). Dalam tesisnya, Muis (2010), berdasarkan beberapa sumber lisan, juga memaknai karakter orang Moronene dengan menarik relasi pada sifat tumbuhan moronene yang menjadi dasar penamaan suku Moronene. Menurutnya, filosofi yang terkandung dalam karakter tumbuhan moronene mengisyaratkan dinamika peradaban leluhur suku Moronene sebagai petani, peramu, dan pemburu yang senang hidup berkelompok pada daerah yang subur dan aman dari gangguan musuh. Lebih jauh, Muis menyimpulkan karakter orang Moronene dalam menghadapi dinamika kehidupannya, umumnya mereka mengidentikkan diri sebagai komunitas adat yang menjunjung tinggi nilai-nilai kedamaian, ketenangan, dan kesederhanaan.

Dengan mengangkat fokus logika semiotik kepemimpinan, permasalahan penelitian ini adalah bagaimanakah pandangan orang Moronene di dalam kalimat penobatan raja $^{3}$ dalam legenda "Donsiolangi dan Wa $\mathrm{Lu}$ Ea" tentang kepemimpinan? Penelitian ini dilakukan untuk memeroleh pemahaman bagaimana orang Moronene di Kabaena bernalar secara filosofis tentang arti sebuah

${ }^{2}$ Sebagian suku Moronene mendiami wilayah daratan Sulawesi Tenggara dan sebagian lagi mendiami Pulau Kabaena. Secara administratif tempat bermukim suku Moronene ini adalah Kabupaten Bombana.

3 Untuk memudahkan penyebutan, penulis menggunakan istilah kalimat penobatan raja, meskipun di dalam legenda "Donsiolangi dan Wa Lu Ea", kalimat-kalimat tersebut merupakan pesan Baginda Mokole Tebota Tulanggadi kepada putranya yang akan ditinggalkan dan diberi tugas mengurusi kerajaan. Pada kenyataannya, kalimat-kalimat ini dijadikan bagian dari rangkaian kalimat penobatan mokole (raja) di Kabaena hingga saat ini (wawancara dengan Ilfan Nurdin, S.Ag.). kepemimpinan, lalu membuat representasinya dalam bentuk beberapa kalimat yang tersisip di dalam rangkaian kalimat penobatan rajanya. Representasi yang muncul di dalam kalimat-kalimat penobatan ini menunjukkan kedalaman berpikir dan berlogika penciptanya. Karena pencipta legenda ini bersifat kolektif, dapat diartikan kualitas logika kolektif orang Moronene di Kabaena terwakili di situ. Legenda sebagai produk budaya komunal, dianggap dapat dijadikan model representasi cara bernalar kelompok tersebut.

Van Zoest mengartikan semiotika sebagai ilmu tanda 'sign' dan segala yang berhubungan dengannya: cara berfungsinya, dan penerimaanya oleh mereka yang mempergunakannya (Sobur, 2006). Dalam semiotika, sederetan objek, peristiwa, dan seluruh kebudayaan dianggap sebagai tanda. Bertolak dari pemahaman ini, semiotika mencakupi wilayah kajian yang cukup luas. Berbagai ranah penelitian dapat dianalisis dengan memanfaatkan pendekatan semiotika. Alam semesta yang luas merupakan sistem tanda yang sangat besar. Di dalamnya terdapat bagian-bagian yang dimungkinkan untuk disekat demi menghasilkan pembahasan yang mendalam.

Penggunaan teori semiotika dalam wilayah penelitian sastra, termasuk sastra lisan yang kemudian dituliskan, merupakan kelanjutan dari praktik pendekatan struktural. Struktural klasik yang memperlakukan karya sastra sebagai sebuah kesatuan otonom an sich, dikembangkan menjadi struktural dinamik. Sastra tersusun atas unsur-unsur yang saling berhubungan satu sama lain. Kurnianto (2015) mengatakan bahwa untuk dapat menemukan makna atau arti karya sastra secara utuh, pembaca atau penikmatnya harus mampu menguraikan sekaligus membaca keterkaitan antarunsur pembentuknya. Dengan penelitian struktural dinamik, sebuah karya sastra dianggap memiliki dua fungsi yang saling melekat satu dengan lainnya, yaitu fungsi 
otonom dan fungsi informasional yang di dalamnya meliputi fungsi penyampai pikiran, perasaan, dan gagasan (Sayuti, 2012: 86).

Dalam menganalisis karya sastra, peneliti tidak dapat melepaskan diri dari menempatkan bahasa sebagai objek penelitian karena media sastra adalah bahasa. Bahasa itu sendiri adalah bahan yang sudah memiliki konvensi terlebih dahulu. Hal yang menarik dalam penelitian berobjek karya sastra adalah karena adanya konvensi ketidaklangsungan ekspresi dan konvensi hubungan antarteks. Pengarang, dalam mengamanatkan gagasannya di dalam tulisan (karya sastra), tidak akan mengungkapkannya dalam sebuah rangkaian kalimat yang informatif tanpa selubung. Ada pertimbangan aspek etis dan estetis dalam penciptaan kalimatkalimat bernilai sastra. Ketidaklangsungan ekspresi dalam sebuah karya sastra dapat berupa penggantian arti, penyimpangan arti, dan penciptaan arti (Riffaterre dalam Pradopo, 2012: 95).

Karya sastra sebagai produk budaya menempatkan latar budaya sebagai aspek yang penting dalam mendalami maknanya. Pemaknaan teks sastra dengan mempertimbangkan aspek budaya tidak akan dapat dilepaskan dari pemaknaan konotatif. Danesi (2010: 17) menyatakan bahwa kebanyakan makna yang dimiliki tanda dalam latar budaya adalah makna konotatif. Dia juga berpendapat bahwa secara fundamental, budaya dapat diklasifikasikan sebagai sistem makna konotatif yang sangat luas yang berkenaan dengan "kode makro" asosiatif yang memungkinkan anggota budayanya untuk berinteraksi sepenuh tujuan serta untuk merepresentasikan dan memikirkan dunia dengan cara tertentu. Berbekal pendapat ini, dapat dikatakan bahwa produk budaya, terutama budaya klasik, seperti cerita lisan, merupakan representasi pandangan dan pemikiran kolektif masyarakat pendukungnya, termasuk legenda "Donsiolangi dan Wa Lu Ea".
Dalam kaitannya dengan kedua fungsi karya sastra yang telah disebutkan di atas, pendekatan semiotika dalam menganalisis karya sastra melibatkan dua tahap pembacaan. Kedua tahap ini lazim disebut sistem semiotik tingkat pertama 'first order semiotics' dan sistem semiotik tingkat kedua 'second order semiotics'. Sistem semiotik tingkat pertama dilakukan pada bahasa sebagai media penyampai karya, sedangkan sistem semiotik tingkat kedua diaplikasikan pada aspek sastranya.

\section{B. METODE PENELITIAN}

Penelitian ini menerapkan metode kualitatif yang lebih berkepentingan dengan persoalan "makna". Makna inilah yang selanjutnya membawa pada orientasi teoretisnya. Sebagai sebuah produk budaya, karya sastra dapat dianggap sebagai masyarakat sehingga dapat dianalisis secara langsung. Hal ini merupakan salah satu konsensus dalam ranah kajian budaya (Ratna, 2010: 197).

Sumber data penelitian berupa data lisan legenda "Donsiolangi dan $\mathrm{Wa} \mathrm{Lu}$ Ea"4. Bagian dari legenda yang dijadikan data adalah lima kalimat yang diucapkan oleh Tebota Tulanggadi kepada putranya ketika dia akan pergi menyusul Tebota Wulele Waru ke kayangan. Kelima kalimat ini dianggap memuat pandangan filosofis orang Moronene atas posisi seorang raja sebagai pemimpin negeri karena hingga saat ini digunakan sebagai salah satu bagian dari rangkaian kalimat penobatan raja atau mokole Moronene di Pulau Kabaena.

Data dianalisis dengan pendekatan semiotik. Analisis terbagi menjadi dua tahap, yaitu analisis heuristik (pembacaan sistem semiotik tingkat pertama) dan analisis retroaktif (pembacaan sistem semiotik tingkat kedua). Pendekatan semiotik dipandang cocok diterapkan dalam menganalisis data, karena data

\footnotetext{
4 yang dituturkan oleh informan Ilfan Nurdin, S.Ag., seorang pemangku adat Moronene di Kabaena yang sekarang sudah dinobatkan menjadi Mokole di Kabaena.
} 
mengandung konvensi sastra yang memerlukan pembacaan lanjutan untuk menjawab permasalahan.

\section{HASIL DAN BAHASAN}

Secara geografis, Pulau Kabaena yang terletak di Provinsi Sulawesi Tenggara berbatasan dengan Selat Kabaena di bagian utara, Laut Flores di sebelah Selatan, Selat Muna dan sebagian Laut Flores di sebelah Timur, dan Teluk Bone di sebelah Barat (pulaukabaena.blogspot.co.id). Sementara itu, secara administratif Pulau Kabaena masuk dalam wilayah Kabupaten Bombana yang secara historis merupakan bekas wilayah Kerajaan Moronene. Kerajaan Moronene yang sudah ada sejak abad ke17 ini oleh pemerintah kontroliur Belanda diubah menjadi distrik-distrik di bawah Kesultanan Buton (bombanakab.go.id). Pada masa awal setelah kemerdekaan RI, eks wilayah Kerajaan Moronene, termasuk Pulau Kabaena, masuk dalam wilayah Kabupaten Buton dan resmi menjadi wilayah otonom dengan nama Kabupaten Bombana sejak 18 Desember 2003 melalui UU No. 29 Tahun 2003.

Sebagai bekas wilayah kerajaan, praktik bersastra secara lisan masih hidup pada masyarakat Moronene di Kabaena. Mereka mengenal seni bercerita tula-tula dan tumburiou (Limba, dkk., 2015). Sebagai produk budaya tradisional, legenda "Donsiolangi dan Wa $\mathrm{Lu}$ Ea" memuat kearifan budaya suku Moronene. Pesan-pesan leluhur dikemas dengan balutan cerita yang pada masanya menjadi inti dalam peradaban kelisanan orang Moronene di Kabaena. Legenda ini memuat kisah yang cukup panjang, dimulai sejak awal peradaban dibangun di Pulau Kabaena, kisah hubungan dengan Kerajaan Gowa, Kesultanan Wolio, hingga masa Belanda datang di Sulawesi Tenggara. Meskipun secara naratif legenda ini terdiri atas satu kesatuan cerita, tetapi di dalamnya terbagi atas segmen-segmen penceritaan dengan fokus tokoh yang berbeda-beda.
Pada penelitian ini, analisis difokuskan pada segmen yang memuat kalimat penobatan raja, yaitu segmen pertama, di mana tokoh di dalam legenda (Tebota Tulanggadi), seorang mokole (raja), berpesan kepada anaknya sebelum ia akhirnya menghilang. Pesan ini dimaksudkan sebagai nasihat dan pedoman bagi sang anak untuk menjalani tugas menggantikan sang ayah sebagai pemimpin kerajaan. Terbaca di dalamnya bagaimana orang Moronene di Kabaena mempersiapkan calon pemimpin mereka, terutama secara mental, melalui rangkaian kalimat-kalimat sang mokole. Apa yang termaktub di dalam pesan mokole ini tentu sudah merupakan hasil pemikiran yang cermat dengan berdasarkan pengalaman sekaligus pengamatan leluhur orang Moronene di Kabaena tentang sosok pemimpin ideal seperti apa yang dibutuhkan oleh masyarakat. Pertimbangan-pertimbangan ini diekstraksi sehingga kalimat yang tercetus dari lisan sang mokole memang kalimat-kalimat padat makna, padat fungsi, dan padat filosofi, demi menghantarkan si calon pemimpin menjadi pemimpin yang baik.

\section{Sinopsis Legenda Donsiolangi dan Wa Lu Ea}

Kisah legenda "Donsiolangi dan Wa $\mathrm{Lu} \mathrm{Ea"} \mathrm{berikut} \mathrm{ini} \mathrm{diperoleh} \mathrm{dari}$ penuturan Bapak Ilfan Nurdin. Dalam penuturannya, beliau juga memberikan informasi mengenai ihwal kalimat penobatan raja di Kabaena. Brikut sinopsis kisahnya.

Alkisah, Donsiolangi dan Wa Lu Ea, putra dan putri Raja Dendeangi dari wilayah Bombana daratan, didampingi tujuh orang pengawal, berlayar menuju Pulau Kabaena. Mereka berlabuh di Wumbu Geresa, dan berniat membuka pemukiman di sana. Sebagai bagian dari upaya diplomasi, kesembilan orang ini merancang sebuah pesta rakyat kokaha ndondouwa' dengan warga setempat. Pesta ini dimaksudkan agar kehadiran mereka 
sebagai pendatang diterima dengan baik oleh penduduk asli Pulau Kabaena.

Dalam persiapan

kokaha ndondouwa, mereka menemukan tiga orang yang kelak menjadi orang penting dalam sejarah Kabaena. Pertama, seorang lelaki rupawan bernama Wakaaka yang ditemukan di dalam ruas bambu gading yang akan mereka jadikan kalemba (alat pikul binatang buruan). Kedua, lelaki berjubah 'duba tongkiwonua' dan menyandang keris 'tobo tongkiwonua' bernama Tebota Tulanggadi, yang ditemukan di dalam ruas bambu hijau besar. Ruas bambu hijau itu sedianya akan digunakan untuk membuat tari (tempat air). Ketiga, seorang perempuan cantik penjelmaan bunga waru yang kemudian dinamai Tebota Wulele Waru. Ketiga orang ini dianggap sebagai anugerah dari langit karena kehadirannya yang tidak lazim.

Selanjutnya, disepakati untuk mengangkat Wakaaka sebagai Turuna Binta Sinangkobino Langi, Tinendeteno Wita (Anugerah Langit Penguasa Alam). Ketika Wakaaka diminta menjadi mokole (raja), dia menolaknya karena menurutnya Tebota Tulanggadi lebih cocok dijadikan mokole setelah dinikahkan dengan Tebota Wulele Waru. Tebota Wulele Waru setuju menikah dengan Tebota Tulanggadi dengan syarat ia tidak memegang najis selamanya. Jadi, Tebota Tulanggadilah yang harus membersihkan segala kotoran anak mereka kelak.

Setelah menikah dan menjadi mokole, Tebota Tulanggadi membangun istana di Eempuu, ibukota Kerajaan Kabaena yang pertama. Sementara itu, Wakaaka pindah ke Rahadopi, sebuah kampung yang selanjutnya ditentukan sebagai kampung pemangku adat. Wakaaka diposisikan sebagai pihak pemangku adat di tanah Kabaena dengan tugas menobatkan mokole dan menjaga jalannya adat istiadat Kabaena. Pemisahan tempat dan fungsi ini dilakukan demi menjaga berjalannya roda pemerintahan. Apabila pemangku adat dan mokole disatukan, dikhawatirkan terjadi mekaumbanga (korupsi, kolusi, dan persepakatan adat) antara kedua belah pihak. Jadi, di Kerajaan Kabena telah disepakati adanya pemisahan fungsi eksekutif dan legislatif sebagai pengawasnya.

Kehidupan rumah tangga Mokole Tebota Tulanggadi dan Tebota Wulele Waru berjalan dengan baik hingga suatu ketika, karena kesibukannya, Sang Mokole menolak mencebokkan putranya yang berhajat besar. Setelah tiga kali diminta dan tiga kali juga menolak, akhirnya Tebota Wulele Waru menceboki anaknya itu. Ini adalah pantangan bagi dirinya sebagai putri kayangan. Akibatnya, ia harus kembali ke kayangan dan meninggalkan keluarganya di bumi. Sepeninggal istrinya, Mokole Tebota Tulanggadi mengasuh anak-anaknya dengan bantuan kungku holue (bagian urusan rumah tangga istana). Mokole hidup sendiri sampai anak-anaknya cukup besar untuk diberi amanah menjadi mokole, melanjutkan roda pemerintahan di Kerajaan Kabaena (dengan restu pihak pemangku adat di Rahadopi).

Mokole Tebota Tulanggadi

bermaksud pergi menyusul Sang Permaisuri ke kayangan. Sebelum pergi, ia berpesan kepada anaknya yang diamanahi menjadi mokole, "Lanjutkan pemerintahan ini, berlakulah adil pada rakyatmu. Pada dirimulah tertuang emas, dan pada dirimulah tertuang sampah. Jika kemarin engkau kuat maka hari ini kamu lemah, jika kemarin engkau lemah maka hari ini kamu kuat. Jika kamu tidak amanah, walau kau besi akan terapung, walau kau sabut akan tenggelam. Karena kau ibarat jarum tempat memasukkan benang". Setelah mengucapkan kalimat-kalimat tersebut, Tebota Tulanggadi menyerahkan pakaian yang dipakainya pada saat ditemukan di buluh hijau lalu dia pergi ke kayangan dan putranya sudah resmi dinobatkan menjadi mokole. 
Pesan Mokole Tebota Tulanggadi kepada anaknya pada paragraf terakhir sinopsis cerita ini (bagian yang dicetak miring) digunakan sebagai salah satu bagian dalam rangkaian kalimat dalam acara penobatan mokole di Kabaena sampai sekarang. Terkait keberadaan Wakaaka di Rahadopi, sampai saat ini pun masih berlaku bahwa penobatan raja 'mokole' di Kabaena dianggap tidak sah tanpa restu dan persetujuan dari pemangku adat di Rahadopi.

\section{Pembacaan Sistem Semiotik Tingkat Pertama (Heuristik) Kalimat Penobatan Raja Kabaena dalam Donsiolangi dan Wa Lu Ea}

$\begin{array}{cccc} & \text { Pesan yang } & \text { diucapkan } & \text { oleh } \\ \text { Tebota } & \text { Tulanggadi } & \text { saat } & \text { akan }\end{array}$ meninggalkan anak-anaknya untuk menyusul sang permaisuri ke kayangan hanya terdiri atas lima kalimat. Namun, dalam praktik sesungguhnya saat ini, kalimat penobatan raja 'mokole' di Kabaena lebih panjang. Kalimat penobatan yang lengkap memuat lebih banyak lagi tuturan-tuturan yang harus dipedomani dalam menjalankan dan membuat kebijakan dalam masyarakat adat serta perihal penyerahan kekuasaan (wawancara dengan Bapak Ilfan Nurdin). Dalam konteks penelitian sastra, kalimat yang dijadikan objek adalah lima kalimat yang ada di dalam legenda "Donsiolangi dan Wa Lu Ea" berikut.

(a) Lanjutkan pemerintahan ini, berlakulah adil pada rakyatmu.

(b) Pada dirimulah tertuang emas, dan pada dirimulah tertuang sampah.

(c) Jika kemarin engkau kuat maka hari ini kamu lemah, jika kemarin engkau lemah maka hari ini kamu kuat.

(d) Jika kamu tidak amanah, walau kau besi akan terapung, walau kau sabut akan tenggelam.

(e) Karena kau ibarat jarum tempat memasukkan benang.

Dalam pembacaan heuristik atau sistem semiotik tingkat pertama, kelima kalimat tersebut dibaca berdasarkan struktur kebahasaannya. Untuk memperjelas $\operatorname{arti}^{5}$ yang terkandung di dalamnya, dimungkinkan adanya penyisipan kata-kata (tambahan, sinonim) sebagai penjelas, dilakukan pembalikan struktur, atau tindakan lain yang menjelaskan kalimat. Berikut ini pembacaan heuristik atas pesan Tebota Tulanggadi kepada putranya.

(a) Lanjutkan(lah) pemerintahan ini, berlakulah adil pada rakyatmu,

(b) (Apabila dirimu berlaku adil) pada dirimulah tertuang emas (puja dan puji dari rakyatmu), dan (apabila dirimu berlaku tidak adil atau berbuat kesalahan) pada dirimulah tertuang sampah (hujatan, caci-maki, dan kritik dari rakyat).

(c) Jika (bisa saja) kemarin engkau kuat maka (dan) hari ini kamu (berubah menjadi) lemah, jika (bisa saja) kemarin engkau lemah maka (dan) hari ini kamu (berubah menjadi) kuat.

(d) Jika kamu tidak amanah, walau kau besi (mungkin saja kau) akan terapung, walau kau sabut (kelapa) (mungkin saja kau) akan tenggelam.

(e) Karena kau (sebagai pemimpin) ibarat jarum, (adalah lubangnya), tempat (orang) memasukkan benang.

Pembacaan heuristik ini belumlah dapat memberikan makna yang sesungguhnya dari rangkaian kalimat Tebota Tulanggadi kepada putranya. Pembacaan ini dilakukan sebatas pada upaya memahami arti bahasa dalam posisi

${ }^{5}$ Dalam pembahasan sistem semiotik tingkat pertama dan sistem semiotik tingkat kedua, dibedakan antara istilah arti dan makna. Istilah arti mengacu pada arti yang terkandung dalam kalimat secara kebahasaan, mengingat pada beberapa bagian, sebuah kalimat perlu disisipi atau diberikan kata penjelas agar artinya dapat lebih dimengerti. Sementara itu, istilah makna digunakan dalam sistem semiotik tingkat kedua, atau pembacaan retroaktif yang tidak lain adalah tahap pemaknaan. Kalimat-kalimat dibaca dengan memperhatikan relasi yang mungkin ditarik kepada aspek lain yang terkait dengan kisah Donsiolangi dan Wa Lu Ea. 
sistem semiotik tingkat pertama, yaitu memahani berdasarkan konvensi bahasanya. Untuk mengungkap makna yang lebih mendalam dari kalimat-kalimat tersebut diperlukan pembacaan lanjutan yang dikaitkan dengan konvensi sastra berupa struktur cerita.

\section{Pembacaan Retroaktif Legenda Donsiolangi dan Wa Lu Ea: Struktur Cerita}

Pembacaan retroaktif dimaksudkan untuk memeroleh pemaknaan teks secara lebih integral. Tahap awal pembacaan retroaktif atau hermeneutik teks sastra adalah menelaah unsur-unsur yang membangunnya. Analisis struktur cerita menjadi hal yang penting dilakukan sebelum memaknai lebih lanjut kalimat perpisahan, yang kemudian menjadi kalimat penobatan, yang diucapkan oleh Tebota Tulanggadi kepada anaknya. Struktur cerita meliputi tokoh dan penokohan, latar, alur, dan tema.

\section{a. Tokoh dan Penokohan}

Ada beberapa tokoh yang terlibat dalam kisah "Donsiolangi dan Wa $\mathrm{Lu} \mathrm{Ea"}$ ini. Dalam analisis tokoh dan penokohan, dilakukan pengelompokan tokoh yang dianggap mewakili satu kepentingan dalam cerita, yaitu Donsiolangi, Wa Lu Ea, dan tujuh pengawal; Wakaaka; Tebota Tulanggadi; dan Tebota Wulele Waru.

\section{Dosiolangi , Wa Lu Ea, dan Tujuh Pengawal}

Kedua tokoh yang dijadikan judul legenda ini sesungguhnya bukanlah tokoh sentral. Akan tetapi, kedudukan mereka sebagai pembuka kisah membuat penutur cerita ini merasa perlu mengabadikan nama keduanya sebagai judul. Donsiolagi ${ }^{6}$ dan Wa Lu Ea adalah putera dan putri Mokole Rumbia (sekarang Bombana daratan), Dendeangi. Mereka diutus ke Kabaena, disertai tujuh orang pengawal

\footnotetext{
${ }^{6}$ Di wilayah Bombana daratan, Donsiolangi dikenal dengan nama Ntina Suropa. Dia adalah putra dari Dendeangi atau Tongkiupuuwonua.
}

kerajaan sejumlah awak kapal, untuk membangun peradaban di pulau tersebut, mengingat saat itu penduduk asli Kabaena belum mengenal sistem kemasyarakatan. Tujuh orang pengawal yang dikisahkan sebagai orang-orang sakti dikelompokkan dengan Donsiolangi dan Wa Lu Ea dalam analisis tokoh karena mereka mewakili satu kepentingan dalam cerita ini. Tidak banyak deskripsi tentang watak tokohtokoh ini. Simpulan terkait perwatakan mereka dilakukan dengan melihat muatan cerita.

Untuk berkenalan lebih dekat dengan penduduk setempat, Donsiolangi, Wa Lu Ea, beserta rombongan sepakat mengadakan pesta rakyat 'kokaha ndondouwa'. Persiapan pesta melibatkan seluruh rombongan dari Rumbia dan penduduk setempat. Mereka berbaur demi terjalinnya kebersamaan dan keberadaan pendatang dari Rumbia dapat diterima oleh penduduk asli. Apabila dilihat dari strategi yang dijalankan untuk meraih simpati dari penduduk asli Kabaena, dapat disimpulkan bahwa Donsiolangi dan $\mathrm{Wa} \mathrm{Lu}$ Ea berwatak terbuka dan berpikiran positif. Tidak ada keinginan untuk menonjolkan diri ataupun menunjukkan kelebihan mereka sebagai pendatang dari tempat yang berperadaban lebih maju.

Watak tersebut dikuatkan dengan kesepakatan mengangkat Wakaaka dan Tebota Tulanggadi sebagai pemimpin dan pemuka adat, alih-alih memosisikan diri sendiri sebagai orang nomor satu di daerah tersebut. Kesepakatan untuk memisahkan fungsi pemimpin pemerintahan (diserahkan kepada tebota Tulanggadi) dan fungsi pemimpin adat (diserahkan kepada Wakaaka) pun menunjukkan sisi positif cara berpikir Donsiolangi da Wa Lu Ea.

\section{Wakaaka, Tebota Tulanggadi, dan Tebota Wulele Waru}

Baik Wakaka, Tebota

Tulanggadi, maupun Tebota Wulele Waru hadir dalam aliran cerita melalui cara yang tidak biasa. Mereka merepresentasikan orang suci yang diturunkan dari langit 
sebagai anugerah bagi penduduk Kabaena. Kemunculan yang gaib membuat masyarakat, termasuk rombongan Donsiolangi, mengistimewakan posisi ketiga orang ini.

Wakaaka ditemukan di dalam seruas bambu gading ketika sekelompok orang bermaksud membuat kalemba untuk mengusung hewan buruan dalam persiapan pesta rakyat. Kutipan cerita berikut memuat peristiwa ditemukannya Wakaaka.

... Kemudian mereka mencari kalemba (pemikul) untuk memikul binatang buruan yang telah berhasil didapat. Mereka menebas bambu gading (awonggadi) untuk dijadikan kalemba. Tiba-tiba terdengar suara suara dari dalam ruas bambu gading yang akan ditebas, "o'oloka (hati2)..!"

Dalam rasa penasaran, mereka menurunkan bambu itu pelan-pelan dan membelahnya dengan hati-hati. Betapa terkejutnya mereka karena ternyata di di dalam ruas bambu kuning itu ada seorang laki-laki dengan wajah rupawan. Setelah ditanyai, laki-laki itu mengaku dirinya bernama Wakaaka. Akhirnya, mereka memutuskan untuk membawa pulang Wakaaka dan binatang buruan yang berhasil mereka tangkap. (Kisah "Donsiolangi dan Wa $\mathrm{Lu}$ Ea", dituturkan oleh Ilfan Nurdin, S.Ag.)

Ketika dicapai mufakat dalam musyawarah Donsiolangi dan kelompoknya untuk menobatkan Wakaaka sebagai raja 'mokole', dengan bijak Wakaaka menolaknya. Dalam pandangan Wakaaka, Tebota Tulanggadi hadir lengkap dengan calon pendampingnya, yaitu Tebota Wulele Waru. Jadi, dialah yang lebih cocok diangkat sebagai raja. Kebijakan Wakaaka terbaca di sini bahwa raja menjadi simbol negeri sehingga harus betul-betul dipilih orang yang secara utuh dapat menjadi kebanggaan seluruh negeri. Sementara itu, Wakaaka sendiri mengambil posisi sebagai pemelihara adat. Setelah pernikahan Tebota Tulanggadi dilangsungkan, ia menikahi salah satu perempuan asli Kabaena. Pernikahan ini memberi gambaran bahwa sebagai orang (yang dianggap) suci, Wakaaka ingin membumikan aturan adat yang kelak akan menjadi pedoman masyarakat setempat.

Wakaaka pun berinisiatif menerapkan pemisahan antara pusat kekuasaan kerajaan yang dipimpin oleh Tebota Tulanggadi dan pusat penjaga dan pemelihara adat yang dipimpinnya. Tugas raja disepakati untuk menjalankan roda pemerintahan, sedangkan tugas pemangku adat adalah menjaga dan memelihara dijalankannya aturan adat di dalam perikehidupan masyarakat.

\section{Tebota Tulanggadi}

Menurut penuturan informan (Bapak Ilfan Nurdin), Tebota Tulanggadi ditemukan oleh kelompok Donsiolangi dan penduduk setempat yang sedang mencari buluh bambu hijau untuk tempat air. Hal itu dilakukan sebagai salah satu persiapan pesta rakyat yang digagas Donsiolangi. Peristiwanya mirip dengan kejadian saat kelompok Donsiolangi menemukan Wakaaka. Yang membedakan adalah jenis bambu dan kepentingan bambu tersebut dipotong.

Tebota Tulanggadi menikahi Tebota Wulele Waru dengan sebuah perjanjian sebagai syaratnya, yaitu Tebota Tulanggadi selaku ayah harus mau membersihkan kotoran anak-anak mereka kelak. Hal ini karena Tebota Wulele Waru sebagai seorang putri bidadari tidak diperbolehkan memegang najis. Tebota Tulanggadi menyadari bahwa pernikahannya dengan Tebota Wulele Waru tidak hanya sekadar untuk kepentingan pribadinya, melainkan juga untuk kepentingan masyarakat di Kabaena secara umum. Dengan dasar pikiran itu, dia menerima syarat yang diajukan oleh Tebota Wulele Waru. Selama bertahuntahun dijalaninya kewajiban membersihkan kotoran anak mereka. Hal 
ini menunjukkan wataknya yang konsekuen atas apa yang telah disepakati. Watak konsekuen ini ditunjukkan pula dengan tanggung jawabnya sebagai orang tua tunggal dalam mengasuh kedua orang anak yang ditinggalkan ibunya kembali ke kayangan.

Setelah kedua anaknya dipandang sudah cukup umur untuk memimpin kerajaan, Tebota Tulanggadi mengutarakan maksudnya menyusul permaisuri ke kayangan. Secara implisit terbaca maksudnya untuk menyerahkan tampuk pemerintahan kepada salah satu anaknya ${ }^{7}$.

Setelah mengucapkan kalimat-kalimat petuah, Tebota Tulanggadi pun menghilang secara gaib. Masyarakat meyakini dia pergi ke kayangan, menyusul Permaisuri Tebota Wulele Waru.

Dari segmen ini, terbaca bahwa Tebota Tulanggadi memiliki sifat visioner. Apa yang akan dilakukannya, terutama yang berkaitan dengan pemerintahan kerajaan, yang berarti terkait dengan hajat hidup orang banyak, terlebih dahulu dipikirkan masak-masak. Bisa jadi, dia semakin penuh pertimbangan setelah keabaiannya terhadap kesepakatan dengan Tebota Wulele Waru. Peristiwa itu sungguh menjadi pelajaran berharga bagi dirinya. Kematangan visi Tebota Tulanggadi terutama sekali terlihat dari kalimat-kalimat petuah yang pada akhirnya dijadikan sebagai kalimat penobatan raja.

\section{Tebota Wulele Waru}

Nama Tebota Wulele Waru berkaitan erat dengan cara kemunculannya. Perempuan cantik ini, sebagaimana Wa Kaaka dan Tebota Tulanggadi, muncul dengan cara yang tidak lazim. Apabila kedua laki-laki rupawan itu muncul dari ruas bambu, Tebota Wulele Waru muncul dari tengah-tengah kelopak bunga waru yang indah. Itulah sebabnya nama Tebota Wulele Waru (Putri Bunga Waru) melekat pada dirinya.

${ }^{7}$ Dalam cerita tidak dijelaskan apakah yang diberi tanggung jawab sebagai raja ini anak pertama atau anak kedua.
Ketika diminta untuk menikah dengan Tebota Tulanggadi, Tebota Wulele Waru mengajukan sebuah syarat. Syarat ini memang harus dia ajukan karena merupakan syarat bagi dirinya untuk tetap bersama dengan keluarganya di bumi apaila benar mereka menikah nanti, yaitu, sebagai putri dari kayangan dia pantang memegang najis. Apabila Tebota Tulanggadi tidak menyepakati syarat tersebut, dia pun tidak akan memaksa, dan akan memilih untuk tidak menikah dengan laki-laki dari ruas bambu hijau itu. Dari ilustrasi ini, dapat diketahui bahwa Tebota Wulele Waru adalah seorang perempuan yang memiliki prinsip. Sebagai perempuan dia tidak hanya menerima apa yang diperintahkan. Dia merasa berhak menerima ataupun menolak sebuah permintaan.

Selain memiliki prinsip, Tebota Wulele Waru pun digambarkan sebagai seorang perempuan yang memiliki kasih sayang serta cinta yang tinggi kepada anak-anaknya dan bersifat konsekuen. Ketika suatu ketika karena suaminya sibuk, meskipun sebetulnya membersihkan kotoran adalah pantangan baginya, dia tetap melakukannya. Dia sangat menyayangi anak-anaknya dan tidak ingin anak tersebut berlama-lama kotor. Konsekuensi pun dijalankannya. Setelah membersihkan kotoran anaknya, dia lenyap, menghilang menuju tempat asalnya di kayangan.

\section{b. Latar Cerita}

Cukup jelas nama-nama tempat yang disebutkan dalam cerita "Donsiolangi dan Wa Lu Ea" ini. Nama Bombana, Tokotu'a, Keuwia, dan Leumbompori merujuk pada lokasi yang secara kultural terikat pada satu kesamaan, yaitu sebagai wilayah asal suku Moronene, baik yang berada di kepulauan maupun daratan. Sementara itu, nama Kabaena, Wumbu Geresa, Sikeli, Rahadopi, Tangkeno, Watorada, dan Eempuu menunjukkan secara khusus nama-nama tempat yang ada di Pulau Kabaena. Demikian pula 
penyebutan nama geografis seperti Gunung Watu Sangia Besar dan Gunung Watu Sangia Kecil, dalam cerita ini menunjukkan tempat-tempat tertentu di Pulau Kabaena. Penyebutan nama-nama secara rinci ini membuat cerita ini semakin meyakinkan sebagai seuah cerita legenda yang benar-benar terjadi sehingga menyerupai sebuah kisah sejarah. Berbeda dengan penyebutan latar tempat yang begitu nyata dan tegas, dalam cerita ini tidak ditemukan penyebutan latar waktu tertentu.

\section{c. Alur dan Tema Cerita}

Cerita bermula dari peristiwa diutusnya Donsiolangi dan rombongannya ke Pulau Kabaena dengan tujuan membangun peradaban di sana. Alur cerita maju dan cenderung datar. Riak konflik terjada saat Tebota Tulanggadi mengabaikan kesepakatannya dengan Tebota Wulele Waru. Akan tetapi, dari penceritaan tidak ada dramatisasi di bagian ini. Kesan dramatis diperoleh dari efek yang ditimbulkan oleh pengabaian Tebota Tulanggadi, yaitu kepergian Tebota Wulele Waru kembali ke kayangan. Kemudian, diikuti kepergian Tebota Tulanggadi sekian tahun kemudian setelah anak-anak mereka cukup dewasa menerima tampuk pemerintahan. Dari konflik itulah, dikisahkan, tercipta perubahan peraturan adat di Kabaena. Jika semula anak-anak raja hanya boleh dibersihkan kotorannya oleh sang ayah, setelah peristiwa ini kungku holue-lah yang berkewajiban membersihkan kotoran para pangeran. Berawal dari konflik itu pulalah terlahir kalimat-kalimat petuah yang kemudian menjadi kalimat penobatan raja di Kabaena.

Tema cerita ini diungkapkan secara eksplisit pada awal cerita, yaitu perintisan peradaban di Pulau Kabaena. Aturan adat pertama yang lahir di sana adalah aturan adat tentang perkawinan. Selanjutnya, setiap peristiwa penting berpotensi untuk menjadi aturan adat yang diberlakukan pada masyarakat.

\section{d. Pembacaan Retroaktif Kalimat Pesan Raja yang Menjadi Kalimat Penobatan Raja Kabaena dalam Legenda Donsiolangi dan Wa Lu Ea}

Dalam pembacaan retroaktif atau hermeneutik ini kalimat penobatan raja dalam legenda Donsiolangi dan Wa Lu Ea dibaca berdasarkan konvensi-konvensi sastra mengacu pada sistem semiotik tingkat kedua. Riffattere dalam Pradopo (2012: 127) mengemukakan ketidaklangsungan ekspresi dalam konvensi sastra yang memberikan makna disebabkan oleh tiga faktor. Ketiga faktor itu adalah penggantian arti, penyimpangan arti, dan penciptaan arti.

a. Lanjutkan pemerintahan ini, berlakulah adil pada rakyatmu.

Kalimat pertama ini merupakan kepala atau inti dari pesan yang diucapkan oleh Tebota Tulanggadi kepada anaknya. Dalam klausa pertama "lanjutkan pemerintahan ini", terbaca makna bahwa dengan kepergiannya nanti menuju kayangan, dia secara serta merta melepaskan dan menyerahkan tanggung jawab pemerintahan kerajaan kepada anaknya. Kata "lanjutkan" mengandung makna bahwa Tebota Tulanggadi meminta anaknya meneruskan cara-caranya memerintah. Apabila dikaitkan dengan tema cerita (perintisan peradaban di Kabaena), bisa jadi, aturan adat saat itu masih sangat dinamis karena masih mencari bentuk dan mekanisme terbaiknya. Langkahlangkah yang pernah dilakukan oleh Tebota Tulanggadi dalam menetapkan aturan adat supaya diikuti dan diteruskan oleh anaknya. Kebijakan raja terdahulu harus dijadikan acuan dan pertimbangan dalam menentukan kebijakan baru.

Klausa kedua, “ ... berlakulah adil pada rakyatmu" menjadi induk bagi tabiat seorang pemimpin, yaitu sifat adil. Keadilan mutlak diperlukan dalam diri seorang pemimpin. Kesehariannya yang harus memimpin warganya membawa 
konsekuenasi bagi dirinya untuk dapat menyelami kalbu-kalbu mereka. Keadilan dalam menentukan solusi setiap permasalahan mutlak harus memenuhi azas keadilan, yaitu tidak berat sebelah, tidak memihak, selalu berpegang pada kebenaran, dan tidak sewenang-wenang.

b. Pada dirimulah tertuang emas, dan pada dirimulah tertuang sampah.

Kalimat kedua memunculkan dua keadaan yang bertolak belakang. Pertama, "pada dirimulah tertuang emas", mengandung makna bahwa seorang raja sebagai pemimpin dapat hidup bergelimang pujian dan sanjungan dari rakyatnya. Keadaan seperti ini hanya mungkin terjadi apabila raja berlaku adil dan bijaksana. Rakyat akan mencintai raja yang adil sepenuh hati. Mereka akan siap membela raja yang adil sebagai junjungannya. Jangankan harta atau tenaga, jiwa pun akan dengan ikhlas dikorbankan demi membela raja yang adil lagi bijak.

Keadaan sebaliknya tergambar dalam klausa kedua "pada dirimulah tertuang sampah". Sampah yang mengandung arti barang atau benda yang dibuang karena sudah tidak dipakai, biasanya merujuk juga pada kata kotor dan secara konotatif bermakna sesuatu yang hina. Seorang raja yang tidak berlaku adil kepada warganya akan terseret pada situasi di mana segala caci-maki, sumpah-serapah, dan hujatan ditujukan padanya. Rakyat yang merasa tidak puas karena diperlakukan tidak adil oleh raja sangat mungkin menempatkan rajanya sendiri pada keadaan seperti itu sehingga lenyaplah segala kewibawaan dan martabat seorang raja.

Kata "emas" mengganti arti 'displacing meaning' pujian, sanjungan, dan pembelaan dari rakyat atau warga, sedangkan kata "sampah" mengganti arti caci-maki, sumpah-serapah, hujatan, dan perlakuan tidak hormat dari mereka. c. Jika kemarin engkau kuat maka hari ini kamu lemah, jika kemarin engkau lemah maka hari ini kamu kuat.

Kalimat ketiga pun terdiri atas dua klausa. Kedua klausa ini dapat dibaca secara lurus, mengandung makna kontradiktif satu sama lain. "Jika kemarin engkau kuat maka hari ini kamu lemah", mengandung makna bahwa mungkin saja sebelum menjadi raja kau dianggap kuat dan bijaksana dalam berpendapat. Namun, begitu menjadi raja keadaan bisa berbalik total. Orang akan mencari kekurangan sekecil apa pun untuk melemahkan posisi rajanya. Hal seperti ini sangat dimungkinkan terjadi mengingat manusia berlainan watak dan perilakunya. Seseorang yang diserahi amanah sebagai raja harus penuh pertimbangan dan kehati-hatian dalam menjalankan tugasnya. Dia tidak dapat lagi berbuat sekehendak hatinya karena tanggung jawab segenap negeri telah beralih ke pundaknya. Faktor suka dan tidak suka dapat menjadi pemicu tindakan atau gerakan bernuansa negatif terhadap pemegang tampuk kekuasaan. Selain faktor suka dan tidak suka dari rakyat, tindakan negatif pun dapat disebabkan oleh ketidakpuasan rakyat akan model kepemimpinan raja. Akumulasi kekecewaan ini menjadi kekuatan bagi rakyat untuk melemahkan posisi raja. Raja menjadi hilang wibawa. Tidak ada lagi rasa hormat rakyat kepada rajanya. Pada akhirnya, kedudukan sebagai raja hanya akan menjadi siksaan dan kehinaan bagi sang raja.

Klausa "jika kemarin engkau lemah maka hari ini kamu kuat" bermakna sebaliknya dari klausa sebelumnya. Jika sebelum menjadi raja kau dianggap lemah, tidak mempunyai daya kekuatan untuk berbuat apa-apa, maka setelah menjadi raja keadaan dapat berbalik 180 derajat. Seorang raja diserahi kekuasaan untuk dapat menggerakkan segenap kekuatan yang ada di dalam 
kerajaannya. Pada tangan seorang rajalah corak, arah, dan nafas sebuah negeri akan menemukan bentuknya. Sebelum menjadi raja mungkin dia tidak dapat memerintahkan rakyat dan perangkat kerajaan untuk berbuat apa pun. Dengan model pengambilan keputusan dan cara menjalankan roda pemerintahan yang penuh pertimbangan serta selalu memperhatikan kepentingan rakyat, seorang raja akan semakin mendapat kepercayaan dari rakyatnya. Rakyat akan dengan senang hati mendukung raja mereka. Cinta dan kasih sayang rakyat menjadi bukti keberhasilan seorang raja. Kepercayaan, dukungan, dan rasa cinta rakyat inilah yang menjadi sumber kekuatan sang raja. Seorang raja harus siap menghadapi situasi apa pun dalam menjalankan tugas-tugasnya.

d. Jika kamu tidak amanah, walau kau besi akan terapung, walau kau sabut akan tenggelam.

Kalimat keempat menggambarkan konsekuensi yang akan dihadapi raja apabila dia tidak amanah dalam menjalankan tugas dan kewajibannya. Jika seorang raja tidak amanah, meskipun dia besi akan terapung. Besi $\mathrm{Fe}$ ) adalah logam keras, kuat, dan berat. Massa jenis besi lebih besar dari pada masa jenis air sehingga menurut hukum alam, besi akan tenggelam ketka dimasukkan ke dalam air. Sementara itu, sabut (kelapa) adalah bagian dari tanaman palma yang bersifat padat tetapi relatif ringan. Massa jenis sabut kelapa lebih rendah dibanding masa jenis air sehingga apabila dimasukkan ke dalam air, akan mengapung atau mengambang. Akan tetapi, karena sesuatu, hukum alam ini dikatakan dapat berbalik keadaannya. Sesuatu yang dapat mengubah hukum alam ini tentulah sesuatu yang sangat dahsyat.

Perumpamaan besi yang dapat terapung di air dan sabut yang tenggelam di air ini dalam sistem semiotik tingkat kedua merupakan konvensi sastra berupa penyimpangan arti 'distorting meaning'. Penyimpangan arti yang terjadi dalam kedua klausa pada kalimat keempat ini berbentuk nonsense atau sesuatu yang tidak masuk akal. Hal ini menunjukkan betapa luar biasanya dampak yang ditimbulkan oleh ketidakamanahan seorang raja.

e. Karena kau ibarat jarum tempat memasukkan benang.

Semua yang dideskripsikan dari kalimat (a) sampai kalimat (d), baik hal positif maupun yang negatif, merupakan konsekuensi bagi seorang raja karena, seorang raja diibaratkan sebagai lubang jarum. Lubang jarum adalah tempat memasukkan benang bagi orang yang hendak menggunakannya, untuk menjahit baju, misalnya. Dengan berhasilnya benang dimasukkan ke dalam lubang jarum, harapan pelakunya adalah dapat teratasinya masalah yang dihadapi, gambarannya seperti pakaian yang robek atau koyak. Seorang raja diharapkan kehadirannya untuk dapat selalu memberikan solusi atas permasalahan yang dihadapi rakyatnya. Rajalah muara berbagai permasalahan negeri. Pada rajalah semua keluh kesah akan disampaikan. Ibarat jarum yang tidak berlubang atau rusak lubangnya sehingga tidak dapat digunakan untuk menjahit, raja yang tidak dapat atau tidak mau menerima keluh kesah, permasalahan, dan pertanyaan rakyatnya, dianggap tidak memiliki kemampuan menduduki posisi sebagai raja.

Penghadiran "lubang jarum" sebagai perumpamaan eksistensi seorang raja merupakan praktik penciptaan arti 'creating meaning'. Lubang pada sebuah jarum dianggap tepat oleh si empunya cerita untuk dijadikan simbol raja yang harus selalu siap sedia menerima apa pun permasalahan yang muncul di negerinya dan harus dibarengi dengan kecakapan mencari solusinya. 
Dari lima kalimat pesan terakhir Tebota Tulanggadi kepada anaknya, sebelum pergi ke kayangan menyusul Tebota Wulele Waru, terdapat empat kalimat yang masing-masing terdiri atas dua klausa dan satu kalimat tunggal. Sebagai bagian dari teks sastra, kalimatkalimat tersebut memanfaatkan konvensi sastra, yakni konvensi ketaklangsungan ekpresi yang membuatnya membutuhkan pembacaan sistem semiotik tingkat kedua. Pada kalimat (a) makna dapat dengan mudah dipahami karena bersifat denotatif. Kalimat (b) mempergantikan makna kata emas dan sampah. Emas menggantikan makna sanjungan dan pujian, sedangkan sampah menggantikan makna hujatan, celaan, dan sumpah serapah. Kalimat (c) sesungguhnya bermakna denotatif, tetapi pemilihan konteks kalimat yang terlalu umum menyebabkannya memerlukan penjelasan lebih lanjut agar dapat dipahami. Penjelasan kalimat (c) bertumpu pada keterangan waktu "kemarin" yang mengacu pada "sebelum dinobatkan menjadi raja" dan "hari ini" yang mengacu pada waktu "setelah dinobatkan menjadi raja". Pada kalimat (d) terjadi konvensi penyimpangan arti 'shifting meaning', di mana besi yang massa jenisnya lebih besar dibanding air dikatakan dapat tenggelam dan sabut kelapa yang massa jenisnya lebih kecil dari air dapat tenggelam. Pernyataan dalam kalimat (d) jelas merupakan situasi yang menyimpang dari hukum alam. Penyimpangan hukum alam ini dikatakan dapat terjadi oleh satu sebab, yaitu tidak amanahnya raja sebagai seorang pemimpin. Kalimat (e) menjadi bukti kreativitas si empunya kisah. Di dalam kalimat ini terdapat konvensi sastra berupa penciptaan arti 'creating meaning'. Di situ, lubang jarum digambarkan mewakili eksistensi seorang raja sebagai muara berbagai masalah sekaligus tempat utama mencari solusi atas masalah-masalah itu.

\section{PENUTUP}

Dari uraian analisis data dalam subbab pembahasan, kelima kalimat pesan
Tebota Tulanggadi kepada putranya, yang kemudian dijadikan kalimat penobatan raja, menyuratkan pandangan orang Moronene atas posisi seorang raja sebagai pemimpin tertinggi sebuah negeri. Dalam pandangan orang Moronene, raja merupakan muara berbagai permasalahan yang terjadi di seluruh negeri sehingga raja harus bersifat amanah dan mutlak berlaku adil kepada rakyatnya. Keadilan dalam menentukan solusi setiap permasalahan mutlak harus memenuhi azas keadilan, yaitu tidak berat sebelah, tidak memihak, selalu berpegang pada kebenaran, dan tidak sewenang-wenang. Kebijakan raja terdahulu harus dijadikan acuan dan pertimbangan dalam menentukan kebijakan baru. Raja memiliki konsekuensi lebih tinggi dibandingkan rakyat biasa, tercermin dari pilihan kata emas dan sampah yang sama-sama berpotensi diterima oleh seorang raja. Kelakuan raja dianggap demikian berpengaruh terhadap kehidupan, baik kehidupan pribadi maupun kehidupan negerinya, secara substansi maupun secara temporal sehingga digambarkan kelakuan yang tidak adil dari sang raja dapat membuat besi mengambang dan sabut kelapa tenggelam di dalam air.

Seseorang yang diserahi amanah sebagai raja harus penuh pertimbangan dan kehati-hatian dalam menjalankan tugasnya. Dia tidak dapat lagi berbuat sekehendak hatinya karena tanggung jawab segenap negeri telah beralih ke pundaknya. Faktor suka dan tidak suka dapat menjadi pemicu tindakan atau gerakan bernuansa negatif terhadap pemegang tampuk kekuasaan. Selain faktor suka dan tidak suka dari rakyat, tindakan negatif pun dapat disebabkan oleh ketidakpuasan rakyat akan model kepemimpinan raja. Seorang raja harus siap menghadapi situasi apa pun dalam menjalankan tugas-tugasnya.

Cara seorang raja memerintah akan membawa dampak yang teramat besar bagi negerinya, baik dampak negatif maupun dampak positif. Hasil kerja seorang raja digambarkan dapat 
membalikkan hukum alam yang sudah menjadi keniscayaan. Sesuatu yang dapat mengubah hukum alam ini tentulah sesuatu yang sangat dahsyat. Rakyat akan mencintai raja yang adil sepenuh hati. Rakyat yang merasa tidak puas karena diperlakukan tidak adil oleh raja sangat mungkin menempatkan rajanya sendiri pada keadaan seperti itu sehingga lenyaplah segala kewibawaan dan martabat seorang raja. Seorang raja diharapkan kehadirannya untuk dapat selalu memberikan solusi atas permasalahan yang dihadapi rakyatnya. Rajalah muara berbagai permasalahan negeri. Pada rajalah semua keluh kesah akan disampaikan. Ibarat jarum yang tidak berlubang atau rusak lubangnya sehingga tidak dapat digunakan untuk menjahit, raja yang tidak dapat atau tidak mau menerima keluh kesah, permasalahan, dan pertanyaan rakyatnya, dianggap tidak memiliki kemampuan menduduki posisi sebagai raja.

\section{DAFTAR SUMBER}

\section{Jurnal}

Hastuti, Heksa Biopsi Puji. 2016.

"Representasi Kultural Laki-laki dan Perempuan dalam Kisah "Putri Lungo" dalam Jurnal Telaga Bahasa Vol. 4 No. 2. Desember 2016. Hlm. 187-206.

Kurnianto, Ery Agus. 2015.

"Analisis Tiga Tataran Aspek Semiotik Tzvetan Todorov pada Cerpen "Pemintal Kegelapan" Karya Intan Paramadhita" dalam Kandai Vol. 11 No. 2. November 2015. Hlm. 206-216

Purnama, Yuzar. 2016.

"Mitologi Saedah Saenih: Cerita Rakyat dari Indramayu” dalam Patanjala Vol. 8 No. 3. September 2016. Hlm. 333-348.

Yulianto, Agus. 2015.

"Kisah Pangeran Suriansyah Membangun Masjid: Suatu Analisis Semiotik" dalam Matrasastra Jurnal Ilmiah Kesastraan Vol. 2 No. 1. Juni 2015. Hlm. 1-14

\section{Buku}

Danesi, Marcell. 2010.

Pesan, Tanda, dan Makna: Buku Teks Dasar Mengenai Semiotika dan Teori Komunikasi (Evi Setyarini dan Lusi Dian Piantari, penerjemah). Yogyakarta: Penerbit Jalasutra.

Limba, Rekson S., dkk. 2015.

Sejarah Peradaban Moronene. Yogyakarta: Penerbit Lukita.

Pradopo, Rachmat Djoko. 2012.

Penelitian Sastra dengan Pendekatan Semiotik. Dalam Jabrohim (Ed.), Teori Penelitian Sastra. Yogyakarta: Pustaka Pelajar.

Ratna, Nyoman Kutha. 2010.

Metodologi Penelitian Kajian Budaya dan Ilmu Sosial Humaniora pada Umumnya. Yogyakarta: Pustaka Pelajar. 2011.

Antropologi Sastra: Peranan Unsurunsur Kebudayaan dalam Proses Kreatif. Yogyakarta: Pustaka Pelajar.

Sayuti, Suminto A. 2012.

Strukturalisme Dinamik dalam Pengkajian Sastra. Dalam Jabrohim (Ed.), Teori Penelitian Sastra. Yogyakarta: Pustaka Pelajar.

Sobur, Alex. 2006.

Analisis Teks Media, Suatu Pengantar untuk Analisis Wacana, Analisis Semiotik, dan Analisis Framing. Bandung: PT Remaja Rosda Karya.

Vansina, Jan. 2014.

Tradisi Lisan sebagai Sejarah. Astrid Reza dkk. (penerjemah), Aditya Pratama (penyunting). Yogyakarta: Penerbit Ombak.

\section{Tesis, Laporan Penelitian}

Muis, Early Wulandari. 2010.

Tumbuhan Moronene: Relasi Antara Budaya dan Falsafah Hidup Masyarakat Moronene. Tesis. Program Studi Antropologi, Program Pascasarjana, Universitas Gadjah Mada, Yogyakarta. 
Hastuti, Heksa Biopsi Puji, Uniawati, \& Rahmawati. 2015.

Inventarisasi Sastra Lisan Sulawesi Tenggara: Sastra Moronene. Laporan Penelitian. Kendari: Kantor Bahasa Provinsi Sulawesi Tenggara.

\section{Prosiding}

Muis, Early Wulandari. 2015.

Adati Totongano Wonua: Identitas Moronene yang Tetap Lestari. Dalam Firman AD \& Sandra Safitri Hanan (Ed.), Prosiding Kongres II BahasaBahasa Daerah Sulawesi Tenggara Tahun 2014, hlm. 202-208. Kendari: Kantor Bahasa Provinsi Sulawesi Tenggara.

\section{Internet}

bombanakab.go.id

(diakses tanggal 18 Oktober 2017)

pulaukabaena.blogspot

(diakses tanggal 18 Oktober 2017)

\section{Informan}

M. Ilfan Nurdin, S.Ag. (Pemuka adat Moronene; Mokole Kabaena) 